\title{
Lipid Constituents of Callus Tissues of Mentha spicata
}

\author{
Takayuki Suga, Toshifumi HiRata and Yoshikazu Yamamoto \\ Department of Chemistry, Faculty of Science, Hiroshima University, \\ Higashisenda-machi, Naka-ku, Hiroshima 730, Japan
}

Received November 30, 1979

\begin{abstract}
A callus tissue culture was established from leaves and stems of Mentha spicata L. Lipid constituents isolated from callus tissues were composed of fatty acids, fatty acid methyl esters, triglycerides, squalene, stigmasterol, sitosterol, oleanolic acid (1), ursolic acid (2) and pomolic acid (3). These liquid constituents did not contain monoterpenoids.
\end{abstract}

Staba et al. ${ }^{1 \sim 3)}$ have reported that callus tissues induced from the stems and the seedlings of $M$. spicata produce carotenoids and xanthophylls. However, constituents other than these compounds have not been investigated yet. In connection with our studies of the biosynthesis of isoprenoids in higher plants, ${ }^{4}$ ) we have conducted callus tissue cultures of $M$. spicata and investigated lipid constituents produced by the callus tissues.

\section{Induction and growth of callus tissues}

In order to determine the optimum nutrition conditions for initiating the callus formation, excised segments of leaves and stems of $M$. spicata were cultured, separately, in the dark at $25^{\circ} \mathrm{C}$ in the $\mathrm{B} 5$ medium $^{5,6)}$ containing either coconut milk (CM) or casein hydrolyzate $(\mathrm{CH})$ as a supplement and 2,4-dichlorophenoxyacetic acid $(2,4-D)$ as an auxin, as shown in Table I. The callus proliferation was facilitated in the media supplemented with $2 \mathrm{ppm}$ and $6 \mathrm{ppm}$ of 2.4-D but became difficult with more than $10 \mathrm{ppm}$ of 2,4-D. Addition of $\mathrm{CH}$ to the B5 medium facilitated the initiation of the leaf callus proliferation, whereas supplying $\mathrm{CH}$ or $\mathrm{CM}$ was not effective for the initiation of the callus proliferation from the stems.

Effects of the supplements and the auxin on the growth of the leaf callus tissues were examined. Addition of $2 \mathrm{ppm}$ of 2,4-D and $0.2 \%$ of $\mathrm{CH}$ to the $\mathrm{B} 5$ medium was found to
TABle I. EFFECTS OF THE SUPPLEMENTS AND THE AUXIN on the Initiation of Callus Proliferation of $M$. spicata IN THE B5 BASAL MEDIUM

\begin{tabular}{|c|c|c|c|c|}
\hline \multirow{2}{*}{$\begin{array}{l}\text { Exp. } \\
\text { No. }\end{array}$} & \multirow{2}{*}{ Supplement } & \multirow{2}{*}{$\begin{array}{l}2,4-D \\
(\mathrm{ppm})\end{array}$} & \multicolumn{2}{|c|}{ Original organs ${ }^{c}$} \\
\hline & & & Stem & Leaf \\
\hline 1 & $\ldots$ & 2 & ++ & + \\
\hline 2 & - & 6 & +++ & + \\
\hline 3 & $\mathrm{CH}^{a}$ & 0 & - & - \\
\hline 4 & $\mathrm{CH}$ & 2 & + & $++t$ \\
\hline 5 & $\mathrm{CH}$ & 6 & $+t$ & ++ \\
\hline 6 & $\mathrm{CH}$ & 10 & - & + \\
\hline 7 & $\mathrm{CM}^{b}$ & 2 & + & ++ \\
\hline 8 & $\mathrm{CM}$ & 6 & + & - \\
\hline
\end{tabular}

a $\quad 0.2 \%(\mathrm{w} / \mathrm{v})$ casein hydrolyzate $(\mathrm{CH})$.

b $15 \%(\mathrm{v} / \mathrm{v})$ coconut milk (CM).

,,,-++++++- ; the relative degree of callus proliferation.

greatly facilitate the growth of the callus, and the growth attained the maximum after a period of 4 weeks, as shown in Fig. 1.

\section{Lipid constituents of the callus tissues}

These callus tissues derived from the leaves and the stems of the plant were, separately, treated with methanol to give a methanol extract, which was then extracted with ether. GLC and TLC of the ether soluble fraction from the stem callus were superimposable on those of the ether soluble fraction from the leaf callus. This indicated that the ether soluble 


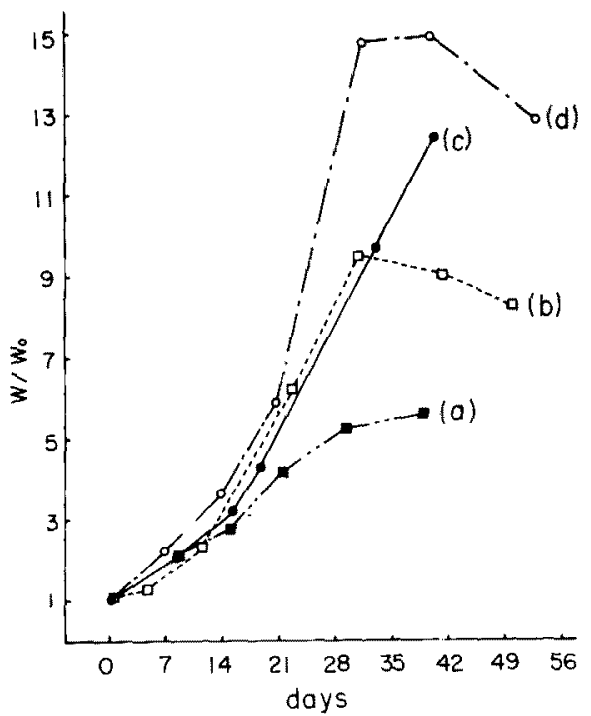

FIG. 1. Effects of the Addition of $\mathrm{CH}$ and 2,4-D on the Growth of Leaf Callus Tissues of $M$. spicata in Various Media.

(a), the B5 medium; (b), the B5 medium with 2 ppm of $2,4-\mathrm{D}$; (c), the B5 medium with $0.2 \%(\mathrm{w} / \mathrm{v})$ of $\mathrm{CH}$; (d), the $\mathrm{B} 5$ medium with $0.2 \%(\mathrm{w} / \mathrm{v})$ of $\mathrm{CH}$ and $2 \mathrm{ppm}$ of $2,4-$ D.

$w / w_{0}$ denotes the ratio of the weight of callus tissues grown during the periods shown to the initial weight of callus tissues used.

fraction of the leaf callus had the same constituents as the ether soluble fraction of the stem callus. Therefore, only the leaf callus fraction was used for identification of constituents thereafter. The ether soluble fraction was chromatographed on a silica gel column to give fatty acid methyl esters, triglycerides, squalene, stigmasterol, sitosterol, fatty acids, oleanolic acid (1), ursolic acid (2) and pomolic acid (3). ${ }^{7,8)}$ The quantities of these constituents

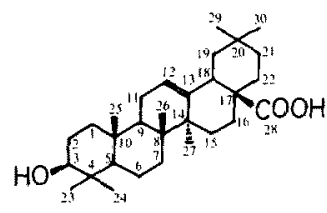

(1)

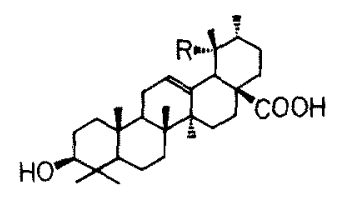

(2) $\mathrm{R}=\mathrm{H}$

(3) $\mathrm{R}=\mathrm{OH}$ are shown in Table II. The presence of a large amount of fatty acid methyl esters suggested that the esters might be due to the use of
Table II. Quantities of the Lipid Constituents IN AN ETHER-SOLUBLE FRACTION OF THE Methanol Extract from the Callus Tissues of $M$. spicata

\begin{tabular}{lc} 
Constituents & $\begin{array}{c}\text { Quantities of the } \\
\text { constituents }(\%)^{a}\end{array}$ \\
\hline Fatty acids & 0.002 \\
Fatty acid methyl esters & 0.041 \\
Triglycerides & 0.017 \\
Squalene & $<0.0001$ \\
Phytosterols & 0.008 \\
Triterpenoids & 0.026 \\
\hline
\end{tabular}

a Expressed as the weight percent of the constituents for the weight of the fresh callus tissues.

$\mathrm{MeOH}$ for the extraction of lipid constituents. However, when the callus was extracted with acetone, in place of $\mathrm{MeOH}$, TLC and GLC analyses of the ether soluble fraction showed the same results as above.

As shown in Table III, palmitic and stearic acids were major fatty acids in the free fatty acids, the fatty acid methyl esters and the triglycerides. Compositions of the phytosterols and the triterpenoids are shown in Table IV. None of the monoterpenoids characteristic of an essential oil of the intact plants of $M$. spicata were found in the ether soluble fraction obtained from the leaf callus tissues. Similar observations have been reported by several workers. $^{9 \sim 11)}$ These results are incompatible with a communication showing that GLC of volatile constituents from cultured cells of Perilla frutescens indicated the formation of some monoterpenoids. ${ }^{12)}$

The lack of the formation of such monoterpenoids may be attributable to the defect of an oil gland in these callus tissues, as Becker ${ }^{11}$ has described that no callus tissues formed an oil gland even when the tissues are induced from an essential oil-producing plant. In addition, it is well known that the redefferentiation ability of callus tissues decreases on subculturing the tissues for a long time. In such a case, a change in the ability to produce monoterpenoids may be expected. However, further investigations are necessary. 
Table III. Fatty Acid Compositions of Free Fatty Acios, Fatty Acid Methyl Esters and Triglycerides Produced by the Callus Tissues of $M$. spicata

\begin{tabular}{|c|c|c|c|c|c|c|}
\hline \multirow{2}{*}{ Constituents } & \multicolumn{6}{|c|}{ Composition of fatty acids $(\%)$} \\
\hline & $16: 0$ & $18: 0$ & $18: 1$ & $18: 2$ & $18: 3$ & Others \\
\hline Free fatty acids & 47.8 & 37.3 & 5.9 & 0 & 9.0 & trace \\
\hline Fatty acid methyl esters & 63.1 & 20.2 & 1.6 & 0 & 3.9 & 11.2 \\
\hline Triglycerides & 43.7 & 14.9 & 12.1 & 0 & 0 & 29.3 \\
\hline
\end{tabular}

Table IV. Compositions of Phytosterols and TTITERPENOIDS FROM THE CALLUS Tissues of $M$. spicata

\begin{tabular}{llc}
\hline Constituents & Compounds & $\begin{array}{c}\text { Composition } \\
(\%)\end{array}$ \\
\hline \multirow{3}{*}{ Phytosterols } & Sitosterol & $\begin{array}{c}82.6 \\
17.4\end{array}$ \\
& Stigmasterol & 21.5 \\
\multirow{3}{*}{ Triterpenoids } & Oleanolic acid (1) & 72.0 \\
& Ursolic acid (2) & 6.5 \\
\hline
\end{tabular}

\section{EXPERIMENTAL}

Mps were determined using a hot plate and are uncorrected. GLC analyses were performed with an instrument with FID and a column $(2 \mathrm{~m} \times 3 \mathrm{~mm})$ packed with $10 \%$ DEGS on Celite $(60 \sim 80$ mesh), $2 \%$ SE-30 on Celite $(60 \sim 80 \mathrm{mesh})$ or $3 \%$ OV -17 on Chromosorb W (80 100 mesh). TLC analyses were carried out with silica gel (Merck $\mathrm{GF}_{254} ; 0.25 \mathrm{~mm}$ thick) using three different solvent systems [(i) EtOAc/hexane $=3 / 7$, (ii) EtOAc/hexane $=1 / 9$ and (iii) $\left.\mathrm{MeOH} / \mathrm{CHCl}_{3}=1 / 19\right]$ for each case.

Tissue cultures from $M$. spicata. The stems and the leaves were sterilized by soaking in $70 \% \mathrm{EtOH}$ for $5 \mathrm{~min}$, followed by immersing in a $10 \%$ bleaching powder solution for $10 \mathrm{~min}$, and then by washing three times with sterilized water. Segments of the stems and the leaves were placed, separately, under sterile conditions in eight kinds of media, as shown in Table I. The cultures were maintained at $25^{\circ} \mathrm{C}$ in the dark. After one to three weeks, a yellowishwhite callus was induced from the plant tissues. The callus growing on the $\mathrm{B} 5$ basal medium supplemented with $0.2 \%$ of $\mathrm{CH}$ and $2 \mathrm{ppm}$ of $2,4 \mathrm{~m}$ was subcultured every four to six weeks for over two years prior to use.

Lipid constituents of the callus tissues. The leaf callus (fresh wt. $1 \mathrm{~kg}$ ) was extracted with $\mathrm{MeOH}$ for $36 \mathrm{hr}$ in a Soxhlet apparatus, through the condenser of which was circulated chilled water. The $\mathrm{MeOH}$ solution was carefully concentrated under slightly reduced pressure. The $\mathrm{MeOH}$ extract of the leaf callus was carefully subjected to TLC and GLC analyses under the conditions shown above and directly compared with the monoterpenoid constituents isolated from intact plants of $M$. spicata. However, none of the monoterpenoid constituents were found.

Then, the MeOH extract was repeatedly extracted with ether. Careful removal of the solvent from the ether solution at atmospheric pressure gave an ether soluble fraction $(4.0 \mathrm{~g})$, which was subjected to TLC and GLC analyses in the same manner as for the $\mathrm{MeOH}$ extract. However, none of the monoterpenoids were found. The ether soluble fraction was then chromatographed on a silica gel column with hexane-EtOAc to give fatty acid methyl esters ( $406 \mathrm{mg}$ ), triglycerides ( $167 \mathrm{mg}$ ), phytosterols $(83 \mathrm{mg})$ and a mixture of fatty acids and triterpenic acids (245 mg).

On the other hand, the stem callus (fresh wt. $20 \mathrm{~g}$ ) was extracted in the same manner as above to give an ether soluble fraction $(65 \mathrm{mg})$. GLC of the ether soluble fraction obtained from the stem callus tissues was superimposable on that of the ether soluble fraction obtained from the leaf callus. TLC of both the fractions also showed completely the same patterns under the conditions given above.

Fatty acid methyl esters and squalene. A 19:1 hexaneEtOAc eluate gave an oily substance ( $406 \mathrm{mg}$ ), which was identified with known samples of fatty acid methyl esters by means of co-GLC. The composition of these fatty acid esters were determined by the peak areas on the GLC chromatogram (Table III). A tiny peak of squalene appeared among these ester peaks. The identity of the hydrocarbon was established by means of co-GLC with an authentic sample.

Triglycerides. A 9:1 hexane-EtOAc eluate afforded a viscous oil: IR $v_{\max }^{\mathrm{Liq}} \mathrm{cm}^{-1}: 1740$ and 1160 (ester); NMR $\left(60 \mathrm{MHz}, \mathrm{CDCl}_{3}\right) \delta: 5.34(>\mathrm{CH}-\mathrm{O}-$ or $-\mathrm{CH}=\mathrm{CH}-), 4.22$ $\left(-\mathrm{CH}_{2}-\mathrm{O}-\right.$ ) and 1.53 (straight $\mathrm{CH}_{2}$ chain). This oil was saponified with $5 \% \mathrm{KOH}$ in $\mathrm{MeOH}$ to five the acidic components, which were methylated with $\mathrm{CH}_{2} \mathrm{~N}_{2}$ and identified with respective authentic samples by means of co-GLC (Table III). An aqueous solution separated from the acidic components was concentrated to a small volume and subjected to GLC analysis to identify glycerol. 
Phytosterols. A 7:3 hexane-EtOAc eluate gave white crystals: $m p 139 \sim 140^{\circ} \mathrm{C}$; IR $v_{\max }^{\mathrm{KBr}} \mathrm{cm}^{-1}: 3280(\mathrm{OH}), 1640$ and $1050(\mathrm{C}=\mathrm{C})$; NMR $\left(\mathrm{CDCl}_{3}\right) \delta: 5.33(1 \mathrm{H}, \mathrm{m}$, $-\mathrm{CH}=\mathrm{C}<), 1.00,0.96,0.90,0.78$ and $0.70\left(\mathrm{CH}_{3}\right)$. GLC analysis indicated the crystals to be composed of a $5: 1$ mixture of sitosterol and stigmasterol, based on the peak areas. The identity of these compounds was established by means of co-GLC $\left(2 \% \mathrm{SE}-30 ; 250^{\circ} \mathrm{C}\right)$ with authentic samples.

Fatty acids and triterpenic acids. A 1:1 hexane-EtOAc eluate gave white needles $(245 \mathrm{mg}$ ), a part of which was methylated with $\mathrm{CH}_{2} \mathrm{~N}_{2}$ and subjected to TLC and GLC $\left(10 \%\right.$ DEGS; $\left.180^{\circ} \mathrm{C}\right)$ analyses. The needles were found to be composed of the fatty acids shown in Table III and three triterpenic acids. The fatty acids were identified by means of co-GLC of their methyl esters. The triterpenic acids were isolated and identified to be as described below,

The white needles $(240 \mathrm{mg})$ were chromatographed on a silica gel plate developed continuously with hexaneEtOAc (85:15) to give oleanolic acid (1) (48 mg), ursolic acid (2) (161 mg) and pomolic acid (3) (15 mg). These showed the following physical data: a) oleanolic acid (1), mp $300 \sim 305^{\circ}$, MS m/e (rel. int.): $456\left(\mathrm{M}^{+}, 6\right) 262$ (69) and $203(100)$. The methyl ester of its acetate, mp $220 \sim 222^{\circ}$ (lit, $\left.{ }^{13)} \mathrm{mp} 219 \sim 220^{\circ}\right) ;{ }^{1} \mathrm{H}-\mathrm{NMR}\left(\mathrm{CDCl}_{3}\right) \delta: 5.28(1 \mathrm{H}, \mathrm{m}$, $-\mathrm{CH}=\mathrm{C}<), 4.50\left(1 \mathrm{H}, \mathrm{t}, J=8.0 \mathrm{~Hz},>\mathrm{CH}-\mathrm{OCOCH}_{3}\right)$, $3.63\left(3 \mathrm{H}, \mathrm{s}, \mathrm{COOCH}_{3}\right), 2.04\left(3 \mathrm{H}, \mathrm{s}, \mathrm{O}-\mathrm{COCH}_{3}\right), 1.13(3 \mathrm{H}$, s, $\left.\mathrm{C}(27)-\mathrm{H}_{3}\right), 0.93 \sim 0.86\left(15 \mathrm{H}, 5 \times \mathrm{CH}_{3}\right)$ and $0.73(3 \mathrm{H}, \mathrm{s}$, C(26)- $\mathrm{H}_{3}$ ); b) ursolic acid (2), mp 235 239 ; MS m/e (rel. int.): $456\left(\mathrm{M}^{+}, 3\right), 248(100)$ and $203(68)$. The methyl ester of its acetate, $\mathrm{mp} 241 \sim 242^{\circ}$ (lit, ${ }^{141} \mathrm{mp} 248 \sim 250^{\circ}$ ); ${ }^{1} \mathrm{H}$ NMR $\left(\mathrm{CDCl}_{3}\right) \delta: 5.20(1 \mathrm{H}, \mathrm{m},-\mathrm{CH}=\mathrm{C}<), 4.60(\mathrm{IH}, \mathrm{t}$, $\left.J=8.0 \mathrm{~Hz},>\mathrm{CH}-\mathrm{OCOCH}_{3}\right), 3.60\left(3 \mathrm{H}, \mathrm{s}, \mathrm{COOCH}_{3}\right), 2.03$ $\left(3 \mathrm{H}, \mathrm{s}, \mathrm{O}-\mathrm{COCH}_{3}\right), 1.07\left(3 \mathrm{H}, \mathrm{s}, \mathrm{C}(27)-\mathrm{H}_{3}\right), 0.94 \sim 0.86$ (15H, methyl signals) and $0.75\left(3 \mathrm{H}, \mathrm{s}, \mathrm{C}(26)-\mathrm{H}_{3}\right)$ and $\left.\mathrm{c}\right)$ pomolic acid (3), $\mathrm{mp} 281 \sim 285^{\circ}$. The methyl ester of its acetate, mp $250 \sim 251^{\circ}$ (lit. ${ }^{7}$ mp $248 \sim 249^{\circ}$ ); MS m/e (rel. int.): $528\left(\mathrm{M}^{+}, 2\right), 468(8), 179(34)$ and $43(100) ;{ }^{1} \mathrm{H}-\mathrm{NMR}$ $\left(\mathrm{CDCl}_{3}\right) \delta: 5.38(1 \mathrm{H}, \mathrm{m},-\mathrm{CH}=\mathrm{C}<), 4.53(1 \mathrm{H}, \mathrm{t}$, $\left.J=8.0 \mathrm{~Hz},>\mathrm{CH}-\mathrm{OCOCH}_{3}\right), 3.62\left(3 \mathrm{H}, \mathrm{s}, \mathrm{COOCH}_{3}\right), 2.60$ $(1 \mathrm{H}, \mathrm{s}, \mathrm{C}(18)-\mathrm{H}), 2.05\left(3 \mathrm{H}, \mathrm{s}, \mathrm{O}-\mathrm{COCH}_{3}\right), 1.28(3 \mathrm{H}, \mathrm{s}$, $\left.\mathrm{C}(29)-\mathrm{H}_{3}\right), 1.23\left(3 \mathrm{H}, \mathrm{s}, \mathrm{C}(27)-\mathrm{H}_{3}\right), 0.95 \sim 0.92(12 \mathrm{H}$, $\left.4 \times \mathrm{CH}_{3}\right)$ and $0.70\left(3 \mathrm{H}, \mathrm{s}, \mathrm{C}(26)-\mathrm{H}_{3}\right)$. The identity of each compound, as indicated by the physical data, was established by comparison (mixed mp, co-TLC, IR and NMR) with the reported data and/or respective samples. $7,8,13 \sim 15$ )

Acknowledgments. The authors thank Dr. K. Ojima, Faculty of Agriculture, Tohoku University, for his valuable advice on the callus tissue proliferation and Professor $E$. Fujita, Chemical Research Institute, Kyoto University, for his generous gift of a sample of methyl ursolate acetate.

\section{REFERENCES}

1) M. L. Lin and E. J. Staba, Lloydia, 24, 139 (1961).

2) C. J. Wang and E. J. Staba, J. Pharm. Sci., 52, 1058 (1963).

3) R. H. Dofferstein and E. J. Staba, Lloydia, 29, 50 (1968).

4) T. Suga, T. Hirata and K. Tange, Chem. Lett., 1975, 243 and our papers cited therein.

5) K. Ojima and O. L. Gamborg, Nippon Dojyo Kagaku Zasshi, 39, 484 (1968).

6) O. L. Gamborg, R. Miller and K. Ojima, Exp. Cell Res., 50, 151 (1968).

7) C. H. Brieskorn and H. Wunderer, Chem. Ber, 100, 1252 (1967).

8) J. Bermejo, J. L. Breton, G. de la Fuente and A. G. Gonzalez, Tetrahedron Lett., 1967, 4649.

9) H. E. Street, G. C. Henshaw and M. C. Buiatti, Chem. \& Ind., 1965, 27.

10) K. H. Overton and D. J. Picken, "Progress in the Chemistry of Organic Natural Products," ed. by W. Herg, H. Geisebach and G. W. Kirby, SpringerVerlag, New York, N.Y., 1977, p. 249.

11) H. Becker, Biochem. Physiol. Pflanz., 161, 425 (1970).

12) H. Sugisawa and Y. Ohnishi, Agric. Biol. Chem., 40 , 231 (1976).

13) S. Matsuura, K. Asano and M. Mizuno, Yakugaku Zasshi, 91, 905 (1971).

14) E. Fujita, T. Fujita and N. Ito, Yakugaku Zasshi, 87, $1150(1967)$.

15) T. Aoki, Y. Tanio and T. Suga, Phytochemistry, 15, 781 (1976). 